\title{
SARS-CoV-2 Removal with a Polyurethane Foam Composite
}

Guilherme Pereira Schoeler

ufpel

Thays França Afonso

ufpel

Carolina Faccio Demarco

ufpel

Victor dos Santos Barboza

ufpel

Tito Roberto Sant'anna Cadaval Jr.

furg

Andrei Valerão Igansi

furg

Marcos Alexandre Gelesky

furg

Janice Luehring Giongo

ufpel

Rodrigo de Almeida Voucher

ufpel

Rafael de Avila Delucis

ufpel

Robson Andreazza ( $\square$ robsonandreazza@yahoo.com.br)

UFPel https://orcid.org/0000-0001-9211-9903

Research Article

Keywords: COVID-19, RT-q PCR, biofoam.

Posted Date: October 26th, 2021

DOl: https://doi.org/10.21203/rs.3.rs-971058/v1

License: (1) This work is licensed under a Creative Commons Attribution 4.0 International License.

Read Full License 


\section{Abstract}

The pandemic of COVID-19 (SARS-CoV-2 disease) has been causing unprecedented health and economic impacts, alerting the world to the importance of basic sanitation and existing social inequalities. The risk of the spread and appearance of new diseases highlights the need for the removal of these pathogens through efficient techniques and materials. This study aimed to develop a polyurethane (PU) biofoam filled with dregs waste (leftover from the pulp and paper industry) for removal SARS-CoV-2 from the water. The biofoam was prepared by the free expansion method with the incorporation of $5 \mathrm{wt} \%$ of dregs as a filler. For the removal assays, the all materials and its isolated phases were incubated for $24 \mathrm{~h}$ with an inactivated SARS-CoV-2 viral suspension. Then, the RNA was extracted and the viral load was quantified using the quantitative reverse transcription (RT-qPCR) technique. The biofoam (polyurethane/dregs) reached a great removal percentage of $91.55 \%$, whereas the isolated dregs waste was $99.03 \%$, commercial activated carbon was $99.64 \%$, commercial activated carbon/polyurethane was $99.30 \%$, and neat PU foam reached was $99.96 \%$ for this same property and without statistical difference. Those new materials endowed with low cost and high removal efficiency of SARS-CoV-2 as alternatives to conventional adsorbents.

\section{Introduction}

The COVID-19 pandemic declared by the World Health Organization (WHO) on March 11, 2020 (WHO, 2020) has spread rapidly around the world causing negative epidemiological, social, economic, cultural and political impacts. SARS-CoV-2 is a positive-sense single-stranded RNA virus belonging to the Coronaviridae family (Polo et al., 2020). This respiratory syndrome may yield certain symptoms, such as fever, cough, shortness of breath, damage to the respiratory, hepatic, neurological systems, and even death in some cases (Kahn; Yadav, 2020; Wong et al., 2019).

This disease is transmitted by droplets from breathing, coughing, sneezing and direct touching (La Rosa et al., 2020), which demanded behavioral changes related to social isolation and closure of institutions for controlling the dissemination of this disease (Nghiem et al., 2020). This virus has high time of incubation and elimination and, besides of that, some infected people remain asymptomatic, which contributes for the current global pandemic scenario (Hart and Halden, 2020).

This pandemic also raised an alarm on the restrict access to sanitation and the social inequalities that exist in the whole world (Daughton, 2020; Street et al., 2020). The current governmental institutions should take into account the eminent risk of spreading of new diseases since COVID-19 is considered the most impactful infectious disease after the Spanish flu pandemic from 1918 (Polo et al., 2020; Hart and Halden, 2020). This is the third outbreak due to a viral zoonotic disease in the last two decades, succeeding SARS from 2002 and MERS from 2012 (Nghiem et al., 2020; Tortora et al., 2012).

Some authors also discussed the contamination and retention of SARS-CoV-2 in waters, as well as the potential of this contaminated effluents to infect people (Amoah et al., 2020; Ahmed et al., 2020; 
Bhowmick et al., 2020; Mandal et al., 2020; Xiao et al., 2020). Countries that lack efficient pathogen removal systems may pose a high risk of contamination (Bhowmick et al., 2020) and the pathway and rate of virus breakdown may vary depending on piping, septic tank employment, and watershed size (Polo et al., 2020). The development of materials for disease protection, disease detection, and water treatment is critical to efforts toward stopping the pandemic of COVID-19 since to control emerging pathogens in wastewater may mitigate the risk against public health (Tang et al., 2020; Lahrich et al., 2021).

Polyurethane (PU) foams are important engineering materials for acoustic and thermal insulation, automotive industry, household and marine applications (Akindoyo et al., 2016; Cinelli et al., 2013; Delucis et al., 2018; Tan et al., 2011). Distinct fillers incorporated in polymer foams have been yielding cellular materials with low environmental impact and low cost (Brito et al., 2011; Tan et al.; 2011), as well as increased performance for several applications (Barreto et al., 2016; Brito et al., 2011; Cinelli et al., 2013).

Brazil was the world's second largest producer of cellulosic pulp in 2018 (IBÁ, 2019) with intense participation in technological development and industrial facilities with high productivity (Moura et al., 2018). This basic raw material of paper is majorly produced following the Kraft process, which aims to dissolve the lignin that connects the cellulosic fibers using sodium salt solutions, although this industrial process also generates woody residues, black liquor, ashes, sludges from effluent treatment plant and residues from chemical recovery, such as dregs, grits, and paper sludge (Alves et al., 2015; Borges et al., 2016).

There are several studies on the application of wastes leftover from the pulp and paper industry in order to reduce their negative environmental impacts, including construction materials (Marques et al., 2014; Mymrin et al., 2016), substrate for soils (Toledo et al., 2015), sanitation applications (Oliveira et al., 2017; Orlandi et al., 2017), and removal of contaminants (Farage et al., 2020). PU bio-foams filled with this type of waste could be applied as a new absorbent for the removal of pathogens from the water since PU foams were already applied as adsorbent supports. The objective of this work was to investigate the application of rigid polyurethane biofoams incorporated with dregs, commercial activated carbon (CAC) and its isolated phases as adsorbents for the removal of SARS-CoV-2 from contaminated water.

\section{Experimental}

\subsection{Preparation of raw materials}

Green liquor dregs wastes were supplied by CMPC located in Guaiba/Brazil. This residue and commercial activated carbon (CAC) (PA, Dinâmica) were dried at $50^{\circ} \mathrm{C}$ and sieved (100-mesh screen; aperture of 150 $\mu \mathrm{m})$. Neat PU, CAC/PU and dregs/PU were prepared by the free expansion method using two mixture components ( $A$ and $B$ ) at a 1:1 NCO/OH ratio and 5\% filler content (Delucis et al., 2018). Component $A$ consisted of castor oil (hydroxyl content of $160 \mathrm{mg} \mathrm{KOH} \cdot \mathrm{g}^{-1}$ ), glycerin P.A., dregs/CAC, chain extender (polyethylene glycol), surfactant (Tegostab B804) and distilled water, which was homogenized for $60 \mathrm{~s}$ at 
$1000 \mathrm{rpm}$ under mechanical stirring and was then left to degas for $120 \mathrm{~s}$. Component $\mathrm{B}$ is catalyst (Tegoamin DMEA) and a polymeric MDI (Diphenylmethane Diisocyanate), which was added to the Component $A$ and then stirred for $20 \mathrm{~s}$ under mechanical agitation. The final mixture was poured into an open mold and left to rise for $24 \mathrm{~h}$. The solid foam was cured at $60^{\circ} \mathrm{C}$ for $2 \mathrm{~h}$ in an oven and post-cured at $65 \%$ relative humidity and $20^{\circ} \mathrm{C}$ for two weeks, as recommended by the literature (Delucis et al., 2018).

\subsection{Scanning electron microscopy (SEM)}

Surface morphologies of the different materials were obtained by scanning electron microscopy (SEM) (JEOL, JSM 6610LV, Japan). The working voltage was $15 \mathrm{kV}$ and the magnification of 100x.

\subsection{X-ray diffraction (DRX)}

X-ray diffraction (XRD) patterns were obtained using a diffractometer (Brunker D-8, Germany), provided with a diffracted beam monochromator and Ni filtered CuKa radiation $(\lambda=1.5406 \AA)$. The voltage was of $40 \mathrm{kV}$ and the intensity of $40 \mathrm{~mA}$. The $2 \theta$ angle was scanned between $10^{\circ}$ and $60^{\circ}$, and the counting time was of $1.0 \mathrm{~s}$ at each angle step $\left(0.02^{\circ}\right)$.

\subsection{Fourier-transform infrared spectroscopy (FT-IR)}

Chemical groups were obtained with Fourier-transform infrared spectroscopy (FT-IR) using IRPrestige-21 (Shimadzu, Japan) scanning from 500 to $4000 \mathrm{~cm}^{-1}, 32$ scans, transmittance mode, and resolution of 4 $\mathrm{cm}^{-1}$.

\subsection{Point of Zero Charge (PZC)}

Point of zero charge (PZC) were obtained using the $24 \mathrm{~h}$ agitation contact at $50 \mathrm{rpm}$ in initial $\mathrm{pH}$ solutions that varied from 1 to 12 . The PZC was obtained after plotting the $\triangle \mathrm{pH}$ ( $\mathrm{pH}$ final - $\mathrm{pH}$ initial) versus initial pH. This methodology was adapted from that described by Farage et al. (2020).

\subsection{SARS-CoV-2 inactivated}

An inactivated SARS-CoV-2 virus used as a positive control and comes from a clinical isolated in Vero-E6 cell culture (SARS.COV-2 / SP02 / human2020 / Br, GenBank accession number MT126808.1). This virus was kindly provided by Prof. Dr. Edison Luiz Durigon from Department of Microbiology, Institute of Biomedical Sciences, University of São Paulo (USP), Brazil (Dorlass et al., 2020).

\subsubsection{Removal of SARS-CoV-2 from the water}

$10 \mathrm{mg}$ of each adsorbent were properly dried at $37^{\circ} \mathrm{C}$ for $2 \mathrm{~h}$. Afterwards, the adsorbent was transferred to a microtube containing $1.5 \mathrm{~mL}$ of ultrapure water (free of all RNAse enzymes) and $150 \mu \mathrm{L}$ of the inactivated SARS-COV-2 viral suspension $\left(2.5 \times 10^{6} \mathrm{copies} / \mathrm{mL}\right)$ was then added, which was followed by incubation with shaking at $200 \mathrm{rpm}$ and $28^{\circ} \mathrm{C}$ for $24 \mathrm{~h}$. Subsequently, both supernatant and adsorbent were removed and placed into another microtube, and the viral RNA was then extracted. 


\subsubsection{RNA extraction}

The RNA was extracted from both supernatant and studied adsorbents using a MagMax ${ }^{\text {TM }}$ Core Nucleic Acid Purification kit (Thermo Fisher Scientific, Waltham, MA, USA). The extracted RNA was quantified by Nano Drop ${ }^{\circledR}$ (Thermo Scientific, Waltham, MA, USA). A concentration of approximately $10 \mathrm{ng}$ of RNA was used to perform the RT-qPCR detection.

\subsection{3 qRT-PCR}

The primer and probe used in PCR reactions was designed according to the sequences published by the Centers for Disease Control and Prevention (CDC, 2020). Briefly, a reaction of $25 \mu \mathrm{L}$ of final volume was used, with the following volumes added to the $1 \times$ concentrated master mix: $5 \mu \mathrm{L}$ of sample RNA, $12.5 \mu \mathrm{L}$ of $2 \times$ reaction buffer, $1 \mu \mathrm{L}$ of Superscript ${ }^{\mathrm{TM}}$ III One-Step with Platinum ${ }^{\mathrm{TM}}$ Taq DNA Polymerase (Invitrogen, Darmstadt, Germany), $0.4 \mathrm{mM}$ of each dNTP, $0.4 \mu \mathrm{L}$ of a $50 \mathrm{mM} \mathrm{MgSO} 4$ solution (Invitrogen), $1 \mu \mathrm{g}$ of non-acetylated bovine albumin (Roche), $10 \mu \mathrm{M}$ of each primer 2019-nCoVN1-F2019-nCoV N1 (5'GACCCCAAAATCAGCGAAAT3'), 2019-nCoVN1-R2019-nCoV N1 (5'TCTGGTTACTGCCAGTTGAATCTG3'), 2019-nCoVN1-P2019-nCoV N1 probe (5'-FAM ACCCCGCATTACGTTTGGTGGACC- BBQ 3'), and DEPC water. The reaction occurred in StepOne ${ }^{T M}$ RealTime PCR System (Thermo Fisher Scientific, Waltham, MA, USA) in the following cycling: $55^{\circ} \mathrm{C}$ for 10 min for reverse transcription, followed by $95^{\circ} \mathrm{C}$ for 3 min and 40 cycles of $95^{\circ} \mathrm{C}$ for $15 \mathrm{~s}, 58^{\circ} \mathrm{C}$ for $30 \mathrm{~s}$.

\subsubsection{Statistical analysis}

Data were expressed as mean \pm standard deviation for duplicates for each experimental point. Data were analyzed by using one-way analysis of variance (ANOVA) followed by Bonferroni's multiple comparison tests adjusted for a significance level of $5 \%$.

\section{Results}

Figure 1 shows SEM images of the studied adsorbents. The dregs and CAC, which were analyzed as received, seems to be composed of rough particles and some aggregates, whereas the neat PU foam and $\mathrm{CAC/PU}$, in turn, presented rounded polymer cells with about $100 \mu \mathrm{m}$ in diameter. Lastly, dregs/PU was mostly composed of irregular shaped cells than CAC/PU.

Figure 2 shows the XRD diffractograms of the studied adsorbents. The dregs (shown in Figure 2a) showed crystallinity with prominent peaks in $2 \theta$ angle of $26^{\circ}, 28^{\circ}, 35^{\circ}, 40^{\circ}, 45^{\circ}, 47^{\circ}$ and $50^{\circ}$ that can be attributed to its high ashes content probably derived from thermally decomposed woods. Compared to the dregs, this crystallinity is smaller for the filled foam. The diffractogram shows a crystalline peak at a $2 \theta$ angle of $28^{\circ}$ associated with the dregs waste. The CAC presented $2 \theta$ angle of $20^{\circ}, 26^{\circ}, 36^{\circ}, 50^{\circ}, 59^{\circ}$ and $67^{\circ}$ predominantly crystalline attributed to the presence of ash resulting from pyrolysis and activating agent outs. With the addition of CAC to polyurethane, there is a suppression of the halo 
existing in $2 \theta$, probably due to the presence of activated carbon, but maintaining the strongly amorphous character of the material.

The spectrum ascribed to the dregs (Figure 3a) present prominent bands at $1390 \mathrm{~cm}^{-1}, 869 \mathrm{~cm}^{-1}$, and 711 $\mathrm{cm}^{-1}$. Based on the spectra of neat and filled PU foams (Figures 3b, 3c, and 3d), it is possible to observe almost the same prominent bands at $3310 \mathrm{~cm}^{-1}, 2837 \mathrm{~cm}^{-1}, 2274 \mathrm{~cm}^{-1}, 1708 \mathrm{~cm}^{-1}, 1513 \mathrm{~cm}^{-1}, 1209 \mathrm{~cm}^{-1}$, and $1042 \mathrm{~cm}^{-1}$. For CAC the bands of $2158 \mathrm{~cm}^{-1}, 2029 \mathrm{~cm}^{-1}, 1978 \mathrm{~cm}^{-1}$ and $1637 \mathrm{~cm}^{-1}$ are characteristic. There were no prominent bands ascribed to the dregs and CAC in the infrared of the filled foam, although both the SEM and XRD results confirmed the presence of this residue in the biofoam structure.

Pzc of dregs was 8.40, CAC was 6.60, neat PU was 6.46, CAC/PU was 6.64, and PUD was 7.14. Associate an influence of the dregs waste in the increase in foam pzc, whereas, the pzc of the material proposed in this study is in a relatively intermediate value between the waste and the pure foam. Both pcz for CAC and neat PU were similar, resulting in the same range for CAC/PU.

Table 1 indicates that the supernatant, neat PU, CAC/PU, and dregs did not differ from each other in terms of CT values. The CT of the materials were similar, for neat PU $31.93 \pm 2.82$, for dregs $28 \pm 0.98$, CAC for $32.68 \pm 5.99$, for CAC/PU 23.12 \pm 0.83 , and for dregs/PU 29.72 \pm 0.40 .

The RT-PCR technique is based on the detection of amplification cycles and is an indirect method for determining viral RNA copies, wherein the CT values are inversely proportional to the viral load (Bustin et al., 2005; Mutesa et al., 2021). In a RT-PCR analysis, the number of viral DNA molecules is doubled at each cycle (Mutesa et al., 2021). A reference number of $2.5 \times 10^{6}$ viral copies per $\mathrm{mL}$ was considered for 15 cycles. In this sense, the viral loads (VC) of adsorbent, supernatant and that removed were not equals.

The CV removed per gram of adsorbent was $4.76 \times 10^{6}$ for the neat PU, $0.91 \times 10^{6}$ for CAC/PU, $0.31 \times 10^{6}$ for CAC, whereas dregs and dregs/PU reached $3.10 \times 10^{6}$ and $0.10 \times 10^{6}$, respectively. Besides of that, an outstanding percentage SARS-CoV-2 removal of $99.03 \%$ was reached for the dregs, whereas this property for the neat PU was $99.96 \%$, 99.64\% for CAC, filled foams were $91.55 \%$ for dregs/PU and $99.3 \%$ for CAC/PU (Fig 5), without statistical difference.

\section{Discussion}

The irregularly shaped particles sometimes forming agglomerates founded for the studied dregs is typical of this industrial solid waste (Mymrin et al., 2016). Diffractogram peaks at $2 \theta$ angles between $25^{\circ}$ and $30^{\circ}$ indicates the presence of a crystalline fraction of calcite $\left(\mathrm{CaCO}_{3}\right)$ and other minor minerals, such as perovskite $\left(\mathrm{Ca}_{4} \mathrm{Ti}_{4} \mathrm{O}_{12}\right)$, dolomite $\left(\mathrm{CaMg}\left(\mathrm{CO}_{3}\right)_{2}\right)$, quartz $\left(\mathrm{SiO}_{2}\right)$, and manganite $\left(\mathrm{Mn}_{4} \mathrm{O}_{8} \mathrm{H}_{4}\right)$ (Mymrin et al., 2016; JIA et al., 2019; Quina and Pinheiro, 2020). The infrared spectrum obtained for the dregs corroborates those reported previous studies, in which intense bands near $1428 \mathrm{~cm}^{-1}, 874 \mathrm{~cm}^{-1}$, and 710 $\mathrm{cm}^{-1}$ indicate the presence of calcium oxides and salts, and magnesium carbonate (Almeida et al., 2007; Matias, 2012). For CAC, MEV indicates abundant pore structure and smooth surface, $2 \theta$ angles of $20^{\circ}$ 
and $25^{\circ}$ represent the presence of carbon and calcium carbonate (Shu et al., 2017), and the bands near $1637 \mathrm{~cm}^{-1}$ indicate the aromatic elongation of C=C (Isik-Gulsac, 2016).

Both neat and filled foams presented a cellular structured marked by numbers open cells, which is normal for PU foams applied as perimeter upstand insulation (Cinelli et al., 2013; Delucis et al., 2018). Also, the incorporation of dregs fillers in PU foams may increase its number of open cells due to some disrupted edges when the filler attaches itself to the polymer cell wall (Delucis et al., 2018). None foams show an organized crystalline phase, which is confirmed by the absence of clear diffraction peaks (Almeida et al., 2020; Schio et al., 2019).

Those prominent bands founded at $3310 \mathrm{~cm}^{-1}$ and $1513 \mathrm{~cm}^{-1}$ are related to the presence of the $\mathrm{N}-\mathrm{H}$ bonds from urethane groups ((-NH-(C=0)-0-) belonging to the PU cell wall (Kumari et al., 2016; Schio et al., 2019; Delucis et al., 2018). That band at $2837 \mathrm{~cm}^{-1}$ is associated with aliphatic groups (Santos et al., 2017; Kumari et al., 2016), whereas the band at $2274 \mathrm{~cm}^{-1}$ represents vibrational modes of $\mathrm{N}=\mathrm{C}=\mathrm{O}$ bonds from isocyanate groups (Santos et al., 2017; Kumari et al., 2016). The latter band may also represent unreacted NCO groups (Schio et al., 2019), which indicates that the dregs imparted a negative effect to the polymerization process, probably related to a steric hindrance mechanism (Delucis et al., 2018).

Pzc measures the potential of the absorbent surface to become positive or negative and is the value at which the net charge of the adsorbent becomes zero. Farage et al. (2020) founded a pzc of 9.75 for a certain dregs waste, which was attributed to its high calcium content. Almeida et al. (2018) reported a pzc of 6.05 for their PU foam, which was related to the generation of surface charges from protonation/deprotonation of $\mathrm{N}-\mathrm{H}$ groups from urethane bonds, which were detected here by the FT-IR analysis.

Viruses are negatively charged colloidal particles with almost neutral $\mathrm{pH}$ values and with the ability to adsorb certain substance onto their surfaces (Lahrich et al., 2021). Some virus removal processes in water treatment occurs due to adsorption between the virus and the suspended solid particles (Bitton, 1975; Gundy et al., 2009). This fact may be associated with the higher removal capacity attributed to the dregs in a comparison with the studied PU foams since the dregs is composed of thin particles endowed with a high surface area, onto which dissolved viruses may be adsorbed.

De Wit et al. (2015) reported viruses (called as nanobacteria) adsorbed onto calcite grains in natural environments. This study corroborates the interaction between viruses and minerals by precipitation processes. Carter et al. (2021) also cited those minerals can have antiviral activities and bind themselves to virus particles.

The removal mechanism is probably related to the active sites from the adsorbents and the $S$ protein of the virus, which is responsible for binding with the host cell (UZUNIAN, 2020). SARS-CoV-2 may be direct adsorbed by electrostatic interactions with oppositely charged surfaces due to $-\mathrm{NH}_{2},-\mathrm{NH}_{3}{ }^{+},-\mathrm{COOH}$ and COO- groups from its amino acids. This could not occur for the studied adsorbents due to their negative 
charge. However, this virus may have a positive charge below its isoelectric point, which could allow the protonation of functional groups and formation of hydrogen bonds (Joonaki et al., 2020). According to Fuhs et al. (1985), electrostatic bonding between mineral surfaces and viruses may occur by Van Der Waals forces.

Carrero et al. (2011) cited that the particle size of milled PU foams may hinder an adhesion mechanism with contaminants since the size defines the "path" that the contaminant has to travel until the binding site. The but irregular cells of the dregs/PU may have negatively inferred in the ability to remove which compare to neat $\mathrm{PU}$ and $\mathrm{CAC} / \mathrm{PU}$.

Even so, both the studied foams showed good results for the removal of SARS-CoV-2 and the dregs insertion yielded an improved removal. A PU-based antimicrobial material developed by Park et al. (2013) also showed antiviral activity with removal capacity of $2.2 \pm 0.3 \times 10^{4} \mathrm{~mL}^{-1}$ and $1.72 .2 \pm 0.4 \times 10^{5} \mathrm{~mL}^{-1}$ for Influenza and Poliovirus, respectively.

Regarding the coronavirus removal in room temperature water, 10 days are required for a $99.9 \% \mathrm{CV}$ removal (Gundy et al., 2009). Haramoto et al., (2020) reported $2.4 \times 10^{3} \mathrm{~L}^{-1} \mathrm{CV}$ of SARS-CoV-2 studding a treated wastewater from Japan. Peccie et al. (2020) announced viral RNA copies that varied from $1.7 \times 10^{3}$ to $4.6 \times 10^{5} \mathrm{~mL}^{-1}$ studding SARS-CoV-2 in primary sludge. Hart and Halden (2020) estimated the presence of 0.15 to $141.5 \times 10^{6} \mathrm{~L}^{-1}$ of SARS-CoV-2 viral genomes studding municipal wastewaters from North America and Europe. The CV removal capabilities found in this study would be sufficient to largely eliminate the viral concentrations reported in the literature.

In pandemic scenarios the control of the water cycle is extremely important to prevent the spread of viruses (Wigginten and Elleberg, 2015), especially in the current SARS-CoV-2 outbreak. Water decontamination practices must be encouraged for an effective removal of microorganisms, viruses, and other contaminants (Amoah et al., 2020; La Rosa et al., 2020).

\section{Conclusion}

Green liquor dregs waste and commercial activated carbon were successfully incorporated into a rigid polyurethane foam and both foam composite and its isolated phases were characterized for chemical and morphological features. All materials were also tested for SARS-CoV-2 removal. Therefore, the surface of this inorganic filler, which is mainly composed of calcite $\left(\mathrm{CaCO}_{3}\right)$, probably chemically bonded itself to the virus. Further studies may address increased filler contents and field tests in contaminated areas.

\section{Declarations}

Funding: This study was partly supported by the Coordenação de Aperfeiçoamento de Pessoal de Nível Superior - Brasil (CAPES) - Finance code 001, by the CNPq (National Council for Scientific and 
Technological Development) and FAPERGS (Research Support Foundation of the State of Rio Grande do Sul).

Acknowledgments This study was financed in part by the Coordenação de Aperfeiçoamento de Pessoal de Nível Superior - Brasil (CAPES) - Finance code 001, by the CNPq (National Council for Scientific and Technological Development) and FAPERGS (Research Support Foundation of the State of Rio Grande do Sul).

\section{Conflict of interest}

The authors declare that they have no conflict of interest.

\section{Ethical Approval}

Not applicable

\section{Consent to Participate}

Not applicable

\section{Consent to Publish}

Not applicable

\section{Authors Contributions}

Guilherme Pereira Schoeler - Material preparation, data collection and analysis were performed

Thays França Afonso - Material preparation

Carolina Faccio Demarco- Material preparatio

Victor dos Santos Barboza- Material preparation,

Tito Roberto Sant'anna Cadaval- Analysis were performed

Andrei Valerão Igansi- Analysis were performed

Marcos Alexandre Gelesky- Analysis were performed

Janice Luehring Giongo- Material preparation,

Rodrigo de Almeida Vaucher- Material preparation, data collection and analysis were performed

Rafael de Avila Delucis- Material preparation

Robson Andreazza- Material preparation, data collection and analysis were performed 
All authors read and approved the final manuscript.

\section{Availability of data and materials}

The datasets used and/or analysed during the current study are available from the corresponding author on reasonable request.

\section{References}

1. Ahmed, W., Angel, N., Edson, J., Bibby, K., Bivins, A., O'brien, J.W., Kitajima, M., Simpson, S.L., Li, J., Tscharke, B., Verhagen, R., Smith, W.J.M., Zaugg, J., Dierens, L., Hugenholtz, P., Thomas, K.V., Mueller, J.F., 2020. First confirmed detection of SARS-CoV-2 in untreated wastewater in Australia: A proof of concept for the wastewater surveillance of COVID-19 in the community. Sci. Total Environ. 728, e138764. https://doi.org/10.1016/j.scitotenv.2020.138764

2. Akindoyo, J.O., Beg, M.D.H., Ghazali, S., Islam, M.R., Jeyaratnam, N., Yuvaraj, A.R., 2016. Polyurethane types, synthesis and applications - a review. RSC Adv., 6, p.114453-114482. http://dx.doi.org/10.1039/c6ra14525f

3. Almeida, H.C., Silveira, C.B., Ernani, P.B., Campos, M.L., Almeida, D., 2007. Composição química de um resíduo alcalino da indústria de papel e celulose (dregs). Quím. Nova 30, 1669-1672. https://doi.org/10.1590/S0100-40422007000700032

4. Almeida, M.L.B, Ayres, E., Moure, C.C., Oréfice, R.L., 2018. Polyurethane foams containing residues of petroleum industry catalysts as recoverable $\mathrm{pH}$-sensitive sorbents for aqueous pesticides. J. HazardousMaterials, 346, 285-295. https://doi.org/10.1016/j.jhazmat.2017.12.033

5. Almeida, M.L.B., Ayres, E., Libânio, M., Gamarano, D.S., Ribeiro, C.C., Oréfice, R.L., 2020. Bio-Based Polyurethane Foams with Enriched Surfaces of Petroleum Catalyst Residues as Adsorbents of Organic Pollutants in Aqueous Solutions. J. Polym. Environ., 28, 2511-2522. https://doi.org/10.1007/s10924-020-01794-9

6. Alves, É.D., Pinheiro, O.S., Da Costa, A.O.S., Costa Júnior, E.F., 2015. Estudo do processo de obtenção celulose Kraft com ênfase no forno de cal. Rev. Liberato, 16, 101-220.

7. Amoah, I.D., Kumari, S., Bux, F., 2020. Coronaviruses in wastewater processes: Source, fate and potential risks. Environ. Int. 143, e105962. https://doi.org/10.1016/j.envint.2020.105962

8. Barreto, F.M., Cunha, R.A.D., Mendes, J.U.L., 2016. Análise térmica de um eco compósito de poliuretano de mamona com rejeito de madeira. Holos, 7, 110-120.

http://dx.doi.org/10.15628/holos.2016.3840

9. Bhowmick, G.D., Dhar, D., Nath, D., Ghangrekar, M.M., Banerjee, R., Das, S., Chatterjee, J., 2020. Coronavirus disease 2019 (COVID-19) outbreak: some serious consequences with urban and rural water cycle. NPJ Clean Water, 3. https://doi.org/10.1038/s41545-020-0079-1

10. Bitton, G., 1975. Adsorption of viruses onto surfaces soil and water. Water Research, 9, 473484.https://doi.org/10.1016/0043-1354(75)90071-8 
11. Borges, M.T., Sigaki, C.K., Cinque, U.C., Contessoto, V.C., 2016. Valorização econômica e ambiental dos resíduos: um estudo de caso da Fibria-MS celulose sul mato-grossense. 0 Papel, 77, 92-97.

12. Brito, G.F., Agrawal, P., Araújo, E.M., Mélo, T.J.A., 2011. Biopolímeros, Polímeros Biodegradáveis e Polímeros Verdes. Rev. Eletron. Mat. Process., 6, 127-139.

13. Bustin, S.A., Benes, V., Nolan, T., Pfaffl, M.W., 2005. Quantitative real-time RT-PCR - a perspective. J. Mol. Endocrinol, 34, 597-601. https://doi.org/10.1677/jme.1.01755

14. Carrero, D.M., Morales, J.M., Garcia, A.C., Florez, N., Delgado, P.A., Dussan, J., Uribe, A.C., Barrios, A.F.G., 2011. Comparative analysis for three different immobilisation strategies in the hexavalent chromium biosorption process using Bacillus sphaericus s-layer. Can. J. Chem. Eng., 89, 1281-1287. https://doi.org/10.1002/cjce.20515

15. Carter, O.W.L., Xu, Y., Sadler, P.J., 2021. Minerals in biology and medicine. RSC Adv., 11, e1939. https://doi.org/10.1039/d0ra09992a

16. CDC. Centers for Disease Control and Prevention, 2020. CDC 2019-Novel Coronavirus (2019-nCoV) Real-Time RT-PCR Diagnostic Panel: Instutions for Use. https://www.cdc.gov/coronavirus/2019ncov/downloads/rt-pcr-panel-for-detection-instructions.pdf (accessed 14 February 2020).

17. Cinelli, P., Anguillesi, I., Lazzeri, A., 2013. Green synthesis of flexible polyurethane foams from liquefied lignin. Euro Polymer J., 49, 1174-1184. https://doi.org/10.1016/j.eurpolymj.2013.04.005

18. Daughton, C.G., 2020. Wastewater surveillance for population-wide Covid-19: The present and future. Sci. Total Environ., 736, e139631. https://doi.org/10.1016/j.scitotenv.2020.139631

19. De Wit, R., Gautret, P., Bettarel, Y., Roques, C., Marlière, C., Ramonda, M., Thanh, T.N., Quang, H.T., Bouvier, T., 2015. Viruses Occur Incorporated in Biogenic High-Mg Calcite from Hypersaline Microbial Mats. PLoS ONE, 10, e0130552. https://doi.org/10.1371/journal.pone.0130552

20. Delucis, R.A., Magalhães, W.L.E., Petzhold, C.L., Amico, S.C. (2018) Forest-based resources as fillers in bio based polyurethane foams. J. Appl. Polym. Sci., 135, e45684. https://doi.org/10.1002/app.45684

21. Dorlass, E.G., Oliveira, C.M., Viana, A. O., et al, 2020. Lower cost alternatives for molecular diagnosis of COVID-19: conventional RT-PCR and SYBR Green-based RT-qPCR [Internet]. Brazilian J. Microbiology, 51, 1117-1123. http://dx.doi.org/10.1007/s42770-020-00347-5

22. Farage, R.M.P., Quina, M.J., Gando-Ferreira, L.G., Silva, C.M., De Souza, J.J.L.L., Torres, C.M.M.E., 2020. Kraft pulp mill dregs and grits as permeable reactive barrier for removal of copper and sulfate in acid mine drainage. Sci. Rep., 10, e4083. http://dx.doi.org/10.1038/s41598-020-60780-2

23. Fuhs, G.W., Chen, M., Sturman, L.S., Moore, R.S., 1985. Virus Adsorption to Mineral Surfaces Is Reduced by Microbial Overgrowth and Organic Coatings. Microb. Ecol., 11, 25-39. https://doi.org/10.1007/BF02015106

24. Gundy, P.M., Gerba, C.P., Pepper, I.L., 2009. Survival of Coronaviruses in Water and Wastewater. Food Environ. Virol, 1, 10-14. https://doi.org/10.1007/s12560-008-9001-6

25. Haramoto, E., Malla, B., Thakali, O., Kitajima, M., 2020. First environmental surveillance for the presence of SARS-CoV-2 RNA in wastewater and river water in Japan. Sci. Total Environ., 737, 
e140405. https://doi.org/10.1016/j.scitotenv.2020.140405

26. Hart, O.E., Halden, R.U., 2020. Computational analysis of SARS-CoV-2/COVID-19 surveillance by wastewater-based epidemiology locally and globally: Feasibility, economy, opportunities and challenges. Sci. Total Environ., 730, e138875. https://doi.org/10.1016/j.scitotenv.2020.138875

27. IBÁ. Industria Brasileira de Árvores (2019) Relatório 2019.

https://iba.org/datafiles/publicacoes/relatorios/iba-relatorioanual2019.pdf (accessed 17 February 2020).

28. Isik-Gulsac, I. 2016. Investigation of impregnated activated carbon properties used in hydrogen sulfide fine removal. Brazilian Journal of Chemical Engineering, 33, 1021-1030, https://dx.doi.org/10.1590/0104-6632.20160334s20150164

29. Jia, Y., Hamberg, R., Qureshi, A., Mäkitalo, M., Maurice, C., 2019. Variation of green liquor dregs from different pulp and paper mills for use in mine waste remediation. Environ Sci Pollut Res, 26, 3128431300. https://doi.org/10.1007/s11356-019-06180-0

30. Joonaki, E., Hassanpouryouzband, A., Heldt, C.L., Areo, O., 2020. Surface Chemistry Can Unlock Drivers of Surface Stability of SARS-CoV-2 in Variety of Environmental Conditions. CHEM, 6, 21352146. https://doi.org/10.1016/j.chempr.2020.08.001

31. Khan, M.H.; Yadav, H., 2020. Sanitization During and After COVID-19 Pandemic: A Short Review. Trans Indian Natl AcadEng, 5, 617-627. https://doi.org/10.1007/s41403-020-00177-9

32. Kumari, S., Chauhan, C.S., Monga, S., Kaushik, A., Ahn, J.H., 2016. New lignin-based polyurethane foam for wastewater treatment. RSC Advances, 6, 77768-77776. https://doi.org/10.1039/c6ra13308h

33. La Rosa, G., Bonadonna, L., Lucentini, L., Kenmoe, S., Suffredini, E., 2020. Coronavirus in water environments: Occurrence, persistence and concentration methods - A scoping review. Water Res., 179, e115899. https://doi.org/10.1016/j.watres.2020.115899

34. Lahrich, S., Laghrib, F., Farahi, A., Bakasse, M., Saqrane, S., El Mhammadi, M.A., 2021. Review on the contamination of wastewater by COVID-19 virus: Impact and treatment. Sci. Total Environ., 751, e142325. https://doi.org/10.1016/j.scitotenv.2020.142325

35. Mandal, P., Gupta, A.K., Dubey, B.K., 2020. A review on presence, survival, disinfection/removal methods of coronavirus in wastewater and progress of wastewater-based epidemiology. J. Environ. Chem. Eng., 8, e104317. https://doi.org/10.1016/j.jece.2020.104317

36. Marques, M.L., Da Silva, E.J., Velasco, F.G., Fornari Junior, C.C.M., 2014. Potencialidade do uso de resíduos de celulose (dregs/grits) como agregado em argamassas. Rev. Bras. Prod. Agroindustriais, 16, 423-431. http://dx.doi.org/10.15871/1517-8595/rbpa.v16n4p423-431

37. Matias, D.V.S., 2012. Análise do potencial de valorização dos resíduos de Licor Verde da Indústria de Pasta de Papel.Dissertation, Universidade de Coimbra.

38. Mosiewicki, M.A., Rojek, P., Michalowski, S., Aranguren, M.I., Prociak, A., 2015. Rapeseed Oil-Based Polyurethane Foams Modified with Glycerol and Cellulose Micro/Nanocrystals. J. Appl. Polym. Sci., 132, e41602. https://doi.org/10.1002/app.41602 
39. Moura, J.M.D., Souza, T.M.D., Lourenço, G.Z., Villegas, T.A.; Pinzón, F.M., 2018. Análise da eficiência energética em segmentos industriais selecionados: Segmento Celulose e Papel. Empresa de Pesquisa Energética; Qualitec-Applus. http://www.epe.gov.br/sites-pt/publicacoes-dadosabertos/publicacoes/PublicacoesArquivos/publicacao-314/topico407/PRODUTO\%204_Vpublicacao.pdf (accessed 17 February 2020).

40. Mutesa, L., Ndishimye, P., Butera, Y., et al, 2021. A pooled testing strategy for identifying SARS-CoV-2 at low prevalence. Nature, 589, 276-280. https://doi.org/10.1038/s41586-020-2885-5

41. Mymrin, V., Cusma, D.F., Nagalli, A., Pichorim, A., Catai, R.E., Pawlowsky, U., 2016. New compositions of the materials from cellulose industry waste. Clean Techn. Environ. Policy, 18, 2007-2017. http://dx.doi.org/10.1007/s10098-016-1129-8

42. Nghiem, L.D., Morgan, B., Donner, E., Short, M.D., 2020. The COVID-19 pandemic: Considerations for the waste and wastewater services sector. Case Stud ThermEng, 1, e100006. https://doi.org/10.1016/j.cscee.2020.100006

43. Oliveira, C.O.M., Pimento, G.H.A., Silva, M.A., Ramos, M.M.M., Siqueira, M.C., Fonseca, Y.A., 2017. Extração da lignina presente no licor negro para adsorção de íons de metais pesados. Percurso Acadêmico, 7, 468-482.

44. Orlandi, G., Cavasotto, J., Machado, F.R.S., Colpani, G.L., Magro, J.D., Dalcanton, F., Mello, J.M.M., Fiori, M.A., 2017. An adsorbent with a high adsorption capacity obtained from the cellulose sludge of industrial residues. Chemosphere, $169,171-180$.

http://dx.doi.org/10.1016/j.chemosphere.2016.11.071

45. Park, D., Larson, A.M., Klibanov, A.M., Wang, Y., 2013. Antiviral and Antibacterial Polyurethanes of Various Modalities. Appl. Biochem. Biotechnol., 169, 1134-1146. https://doi.org/10.1007/s12010012-9999-7

46. Polo, D., Quintela-Baluja, M., Corbishley, A., Jones, D.L., Singer, A.C., Graham, D.W., Romalde, J.L., 2020. Making waves: Wastewater-based epidemiology for COVID-19 - approaches and challenges for surveillance and prediction. Water Res, 186, e116404.

https://doi.org/10.1016/j.watres.2020.116404

47. Quina, M.J., Pinheiro, C.T., 2020. Inorganic Waste Generated in Kraft Pulp Mills: The Transition from Landfill to Industrial Applications. Appl. Sci., 10, e2317. https://doi.org/10.3390/app10072317

48. Santos, O.S.H., Silva, M.C., Silva, V.R., Mussel, W.N., Yoshida, M.I., 2017. Polyurethane foam impregnated with lignin as a filler for the removal of crude oil from contaminated water. J. Hazard Mater., 324, 406-413. https://doi.org/10.1016/j.jhazmat.2016.11.004

49. Schio, R.R., Rosa, B.C., Gonçalves, J.O., Pinto, L.A.A., Mallmann, E.S., Dotto, G.L., 2019. Synthesis of a bio-based polyurethane/chitosan composite foam using ricinoleic acid for the adsorption of Food Red 17 dye. Int J Biol Macromol., 121, 373-380. http://dx.doi.org/10.1016/j.jijbiomac.2018.09.186

50. Shu, J., Cheng, S., Xia, H., Zhang, L., Peng, J., Li, C., Zhang, S. 2017. Copper loaded on activated carbon as an efficient adsorbent for removal of methylene blue. RSC Adv., 7, 14395-14405. https://doi.org/10.1039/C7RA00287D 
51. Tan, S., Abraham, T., Ference, D., Macosko, C.W., 2011. Rigid polyurethane foams from a soybean oilbased Polyol. Polymer, 52, 2840-2846. http://dx.doi.org/10.1016/j.polymer.2011.04.040

52. Tang, Z., Kong, N., Zhang, X. et al, 2020. A materials - science perspective on tackling COVID-19. Nat. Rev. Mater., 5, 847-860. https://doi.org/10.1038/s41578-020-00247-y

53. Toledo, F.H.S.F.De.; Venturin, N.; Carlos, L.; Dias, B.A.S.; Venturin, R.P.; Macedo, R.L.G., 2015. Composto de resíduos da fabricação de papel e celulose na produção de mudas de eucalipto. Rev. Bras. Eng. AgricolaAmbient., 19, 711-716. http://dx.doi.org/10.1590/18071929/agriambi.v19n7p711-716

54. Tortora, G.J.; Berdell, R.F.; Case, C.L., 2012. Microbiologia, tenth ed. Artmed, Porto Alegre.

55. Uzunian, A., 2020. Coronavírus SARS-CoV-2 e Covid-19. J. Bras. Patol. Med. Lab., 56, 1-4. https://doi.org/10.5935/1676-2444.20200053

56. WHO. 2020. WHO Director-General's opening remarks at the media briefing on COVID-19-11 March 2020. https://www.who.int/director-general/speeches/detail/who-director-general-s-opening-remarksat-the-media-briefing-on-covid-19--11-march-2020 (accessed 14 March 2020).

57. Wigginten, K.R., Ellenberg, R.M., 2015. Emerging investigators series: the source and fate of pandemic viruses in the urban water cycle. Environ. Sci.: Water Res. Technol., 1, 735-746. https://doi.org/10.1039/c5ew00125k

58. Wong, A.C.P., Li, X., Lau, S.K.P., Woo, P.C.Y., 2019. Global Epidemiology of Bat Coronaviruses. Viruses, 11, e174. https://doi.org/10.3390/v11020174

59. Xiao, F., Tang, M., Zheng, X., 2020. Evidence for Gastrointestinal Infection of SARS-CoV-2. Gastroenterology, 158, 1831-1833. https://doi.org/10.1053/j.gastro.2020.02.055

\section{Tables}

Table 1 - Cycle threshold (CT), viral load (copies $\mathrm{mL}^{-1}$ ), and removal properties obtained after $24 \mathrm{~h}$ of incubation. 


\begin{tabular}{|c|c|c|c|c|c|}
\hline & PU & dregs & dregs/PU & CAC/PU & CAC \\
\hline Control $\mathrm{C}_{\mathrm{T}}$ & \multicolumn{5}{|l|}{$14.85 \pm 0.96$} \\
\hline $\begin{array}{l}\text { viral load in control (copies } \\
\mathrm{mL}^{-1} \text { ) }\end{array}$ & \multicolumn{5}{|c|}{$2.5 \times 10^{6} \pm 0.11 \times 10^{6}$} \\
\hline Supernatant $C_{T}$ & $20.74 \pm 1.58$ & $21.39 \pm 0.38$ & $26.11 \pm 0.77$ & $23.12 \pm 0.83$ & $24.73 \pm 0.69$ \\
\hline $\begin{array}{l}\text { viral load in supernatant } \\
\text { (copies } \mathrm{mL}^{-1} \text { ) }\end{array}$ & $47.65 \times 10^{3}$ & $31.35 \times 10^{3}$ & $1.14 \times 10^{4}$ & $9.15 \times 10^{3}$ & $3.09 \times 10^{3}$ \\
\hline material $\mathrm{C}_{\mathrm{T}}$ & $31.93 \times 2.82$ & $28 \pm 0.98$ & $29.72 \pm 0.40$ & $30.32 \pm 1.11$ & $32.68 \pm 5.99$ \\
\hline $\begin{array}{l}\text { viral load in material } \\
\text { (copies } \mathrm{mL}^{-1} \text { ) }\end{array}$ & $0.020 \times 10^{3}$ & $0.310 \times 10^{3}$ & $0.097 \times 10^{3}$ & $0.064 \times 10^{3}$ & $0.011 \times 10^{3}$ \\
\hline $\begin{array}{l}\text { viral load removed (copies } \\
\mathrm{mL}^{-1} \text { ) }\end{array}$ & $47.64 \times 10^{3}$ & $31.04 \times 10^{3}$ & $1.05 \times 10^{3}$ & $9.09 \times 10^{3}$ & $3.09 \times 10^{3}$ \\
\hline $\begin{array}{l}\text { viral load removed (copies } \\
\mathrm{mLg}^{-1} \text { ) }\end{array}$ & $4.76 \times 10^{6}$ & $3.10 \times 10^{6}$ & $0.10 \times 10^{6}$ & $0.91 \times 10^{6}$ & $0.31 \times 10^{6}$ \\
\hline
\end{tabular}

Values are mean \pm standard deviation

Figures 


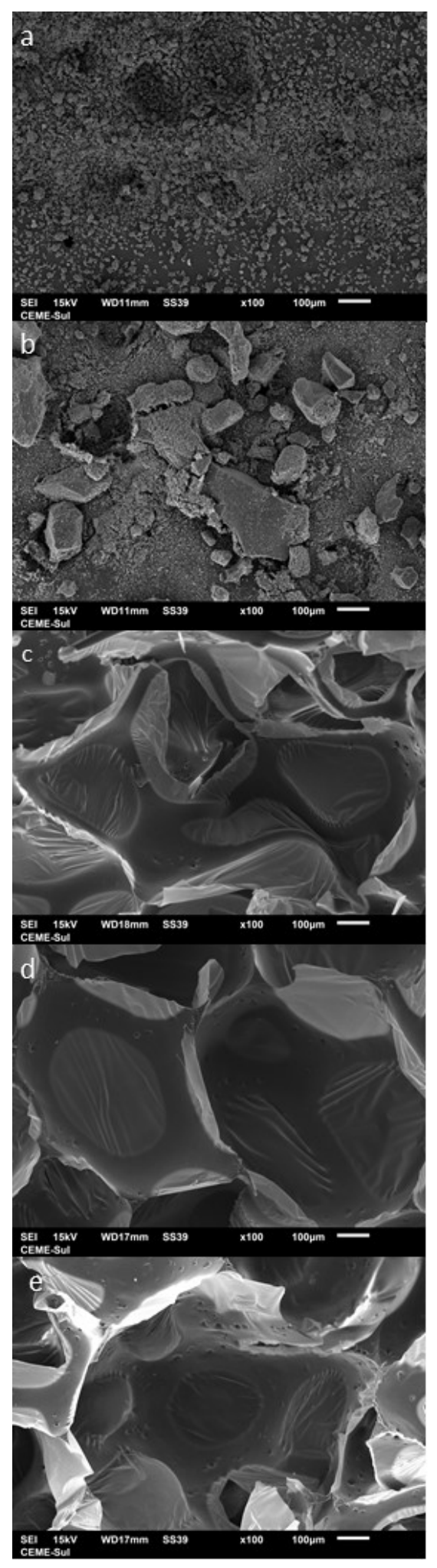

\section{Figure 1}

SEM images for dregs (a), CAC (b), dregs/PU foam (c), CAC/PU (d), andneat PU foam (e). 


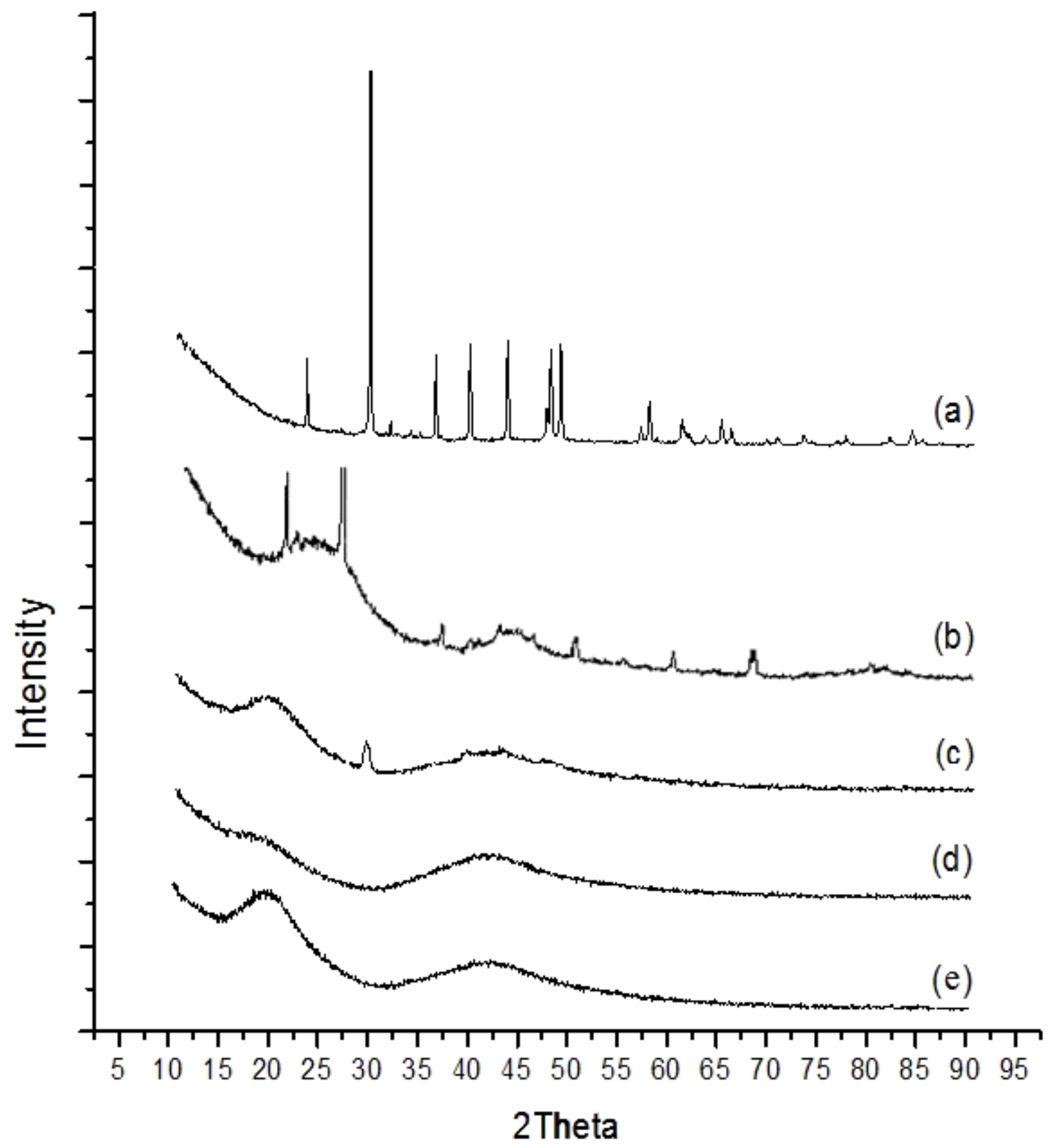

Figure 2

XRD for dregs (a), CAC (b), dregs/PU foam (c), CAC/PU (d), and neat PU foam (e). 


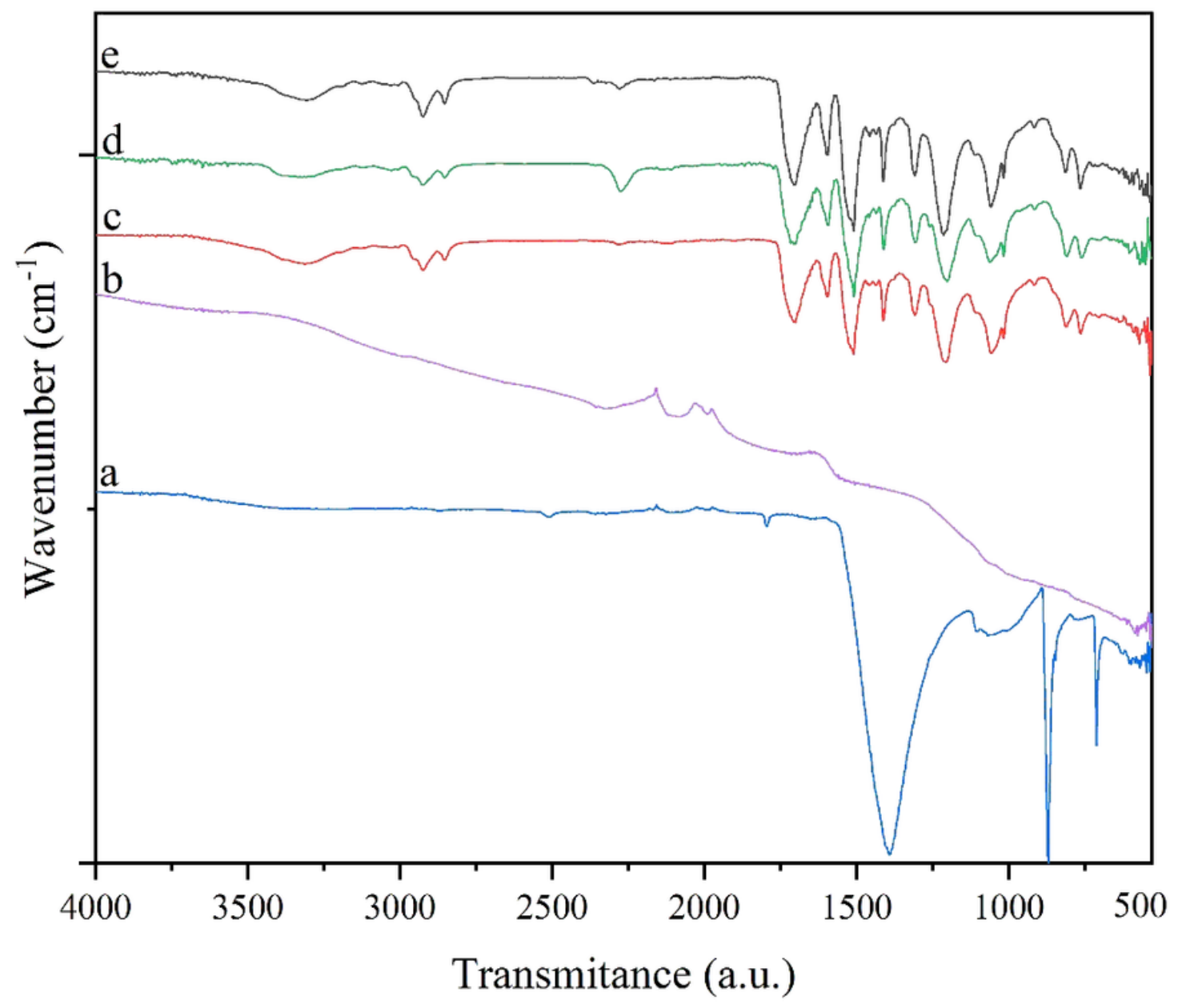

Figure 3

Infrared spectra for dregs (a), CAC (b), dregs/PU foam (c), CAC/PU (d), and neat PU foam (e). 


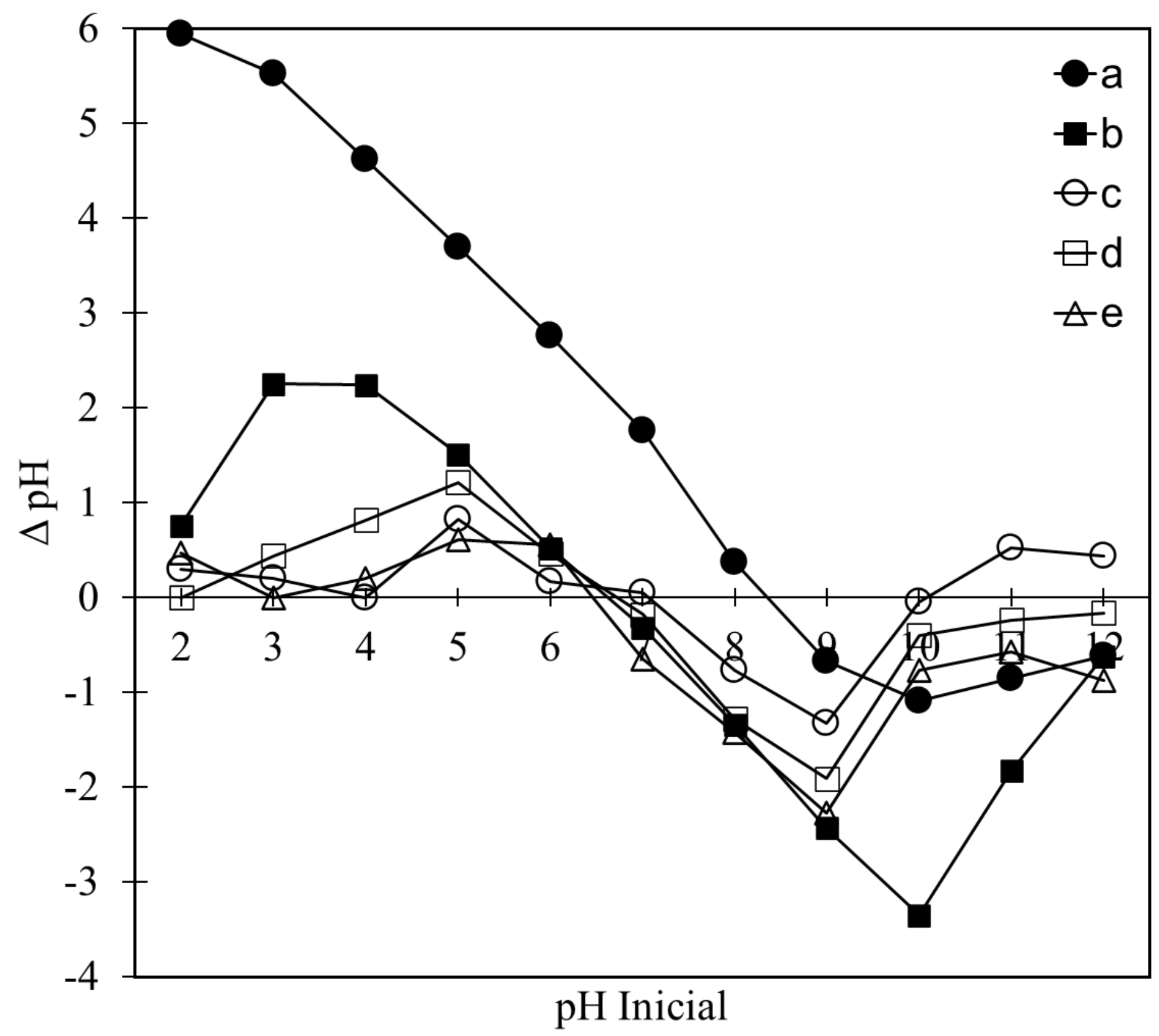

Figure 4

Point zero change for dregs (a), CAC (b), dregs/PU foam (c), CAC/PU (d), and neat PU foam (e). 


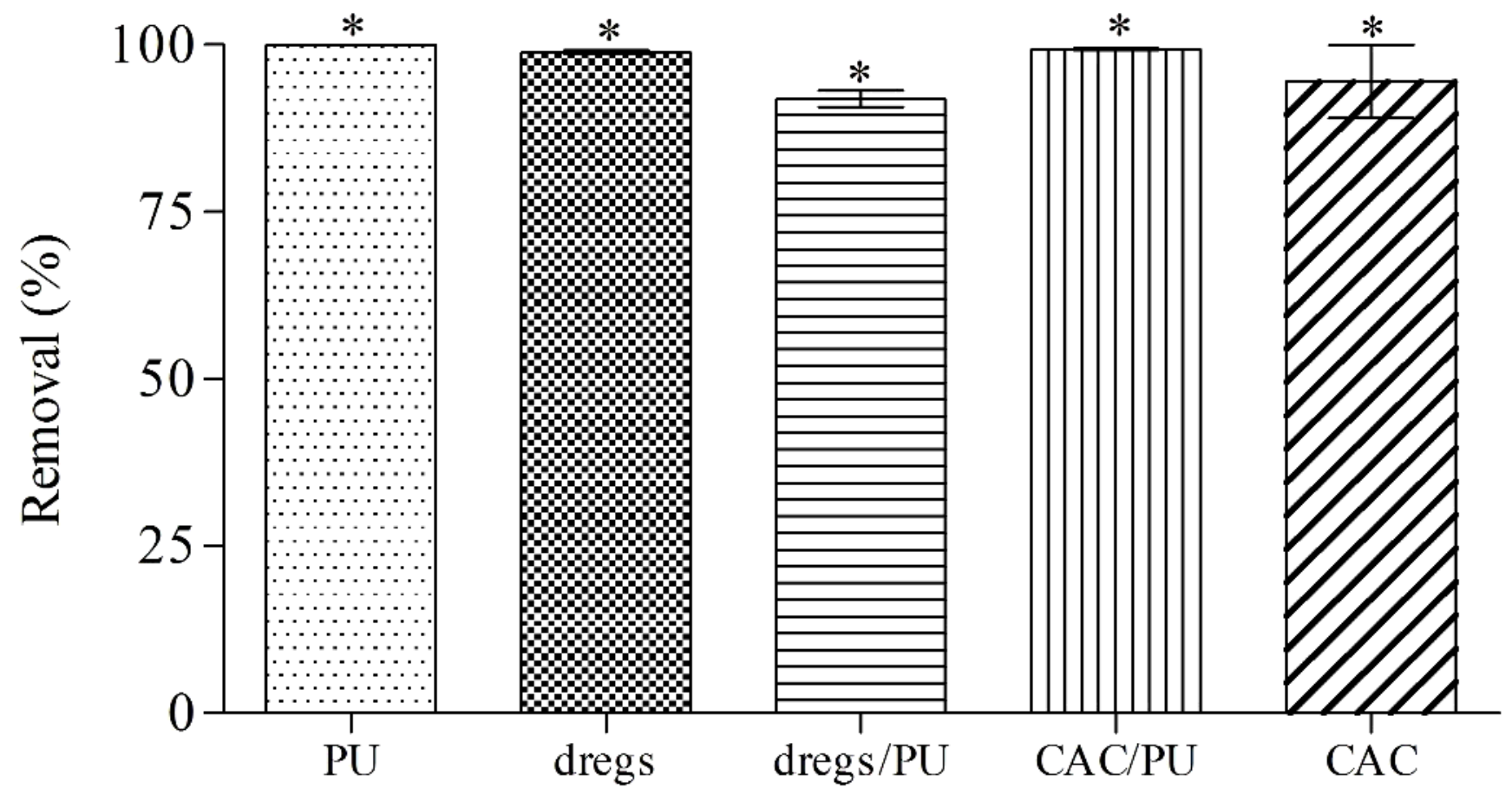

Figure 5

Percentage SARS-CoV-2 removal (\%) of with PU, dregs, dregs/PU, CAC/PU, and CAC. * above the bars represents equal means at a confidence level of $95 \%$. 